\title{
POCZUCIE TOŻSAMOŚCI NARODOWEJ PIELĘGNIAREK W KONTEKŚCIE TENDENCJI GLOBALIZACYJNYCH - PERSPEKTYWA TEORETYCZNA
}

\section{THE SENSE OF NURSES' NATIONAL IDENTITY IN VIEW OF GLOBALIZATIONAL TRENDS - THEORETICAL PERSPECTIVE}

\author{
Grzegorz Konieczny ${ }^{1}$, Renata Rasińska² \\ ${ }^{1}$ Katedra Marketingu i Zarządzania \\ Wyższa Szkoła Hotelarstwa i Gastronomii w Poznaniu \\ ${ }^{2}$ Zakład Organizacji i Zarządzania w Opiece Zdrowotnej \\ Uniwersytet Medyczny im. Karola Marcinkowskiego w Poznaniu
}

DOI: https://doi.org/10.20883/pielpol.2017.21

\begin{abstract}
STRESZCZENIE
Celem niniejszej publikacji jest próba zdefiniowania tożsamości narodowej oraz poczucia tożsamości narodowej pielęgniarek w perspektywie teoretycznej. Autorzy dokonają oceny wybranych elementów, wokół których ogniskują się analizowane terminy. Inspiracją podjętej analizy jest chęć określenia ww. pojęć w kontekście zmieniającej się rzeczywistości społeczno-kulturowej oraz migracji zarobkowych, które dotykają coraz większych grup społeczno-zawodowych, w tym i środowiska pielęgniarek i położnych, a które to dyslokacje, szczególnie długoterminowe, nie pozostają bez wpływu na pojmowanie tożsamości narodowej.

Przedstawiona $w$ tej pracy analiza porusza zagadnienie aksjologicznych korelatów tożsamości narodowej, jak również poczucia tożsamości narodowej. Dokonujące się na naszych oczach zmiany niemal w każdym wymiarze ludzkiego życia, w szczególności narastające zjawisko transgraniczności i towarzysząca jej transkulturowość, które są wynikiem m.in. globalizacji, spowodowały, że współczesny świat społeczny powoli staje się światem jednego narodu. Jak pokazuje analiza literaturowa, w tych zmianach przedstawiciele różnych grup zawodowych, w tym i pracownicy służby zdrowia, dostrzegają dla siebie szanse na lepsze zarobki czy też poprawę warunków pracy. W związku z powyższym istnieje potrzeba modyfikacji lub ponownego definiowania wielu pojęć, w tym tożsamości narodowej, europejskiej czy też poczucia tożsamości narodowej, jak również potrzeba odsłaniania nowych, pełniejszych aspektów zjawiska tożsamości.
\end{abstract}

SŁOWA KLUCZOWE: tożsamość narodowa, poczucie tożsamości narodowej, migracje zarobkowe, pielęgniarki.

Historie są dziełem ludzi z określonymi tożsamościami

P. Berger, T. Luckmann

\section{Wstęp}

Niniejszy artykuł porusza zagadnienie aksjologicznych korelatów poczucia tożsamości narodowej pielęgniarek emigrujących zarobkowo. Czas rozpięty pomiędzy

\begin{abstract}
The aim of this publication is an attempt to define national identity and a sense of nurses' national identity in the theoretical perspective. The authors will evaluate selected elements on which the analyzed terms focus. The inspiration for this analysis is to determine concepts mentioned above in the context of changing socio-cultural reality and economic migrations. They affect larger and larger socio-vocational groups, including the environment of nurses and midwives, and these particularly long-term dislocations are not without impact on the understanding of national identity.

The analysis presented in this article raises the question of axiological correlates of national identity as well as the sense of national identity. Changes that we witness take place in almost every walk of human life. The growing phenomenon of cross-border and transculturalism, which are the result of globalization, among others, make the contemporary social world become the world of one nation. According to literature analysis, representatives of various professional groups, including health professionals, recognize their chances for better wages or improved working conditions in those changes. Therefore, there is a need to modify or redefine many concepts including national identity, European identity or the sense of national identity, as well as the need to reveal new, more comprehensive aspects of the phenomenon of identity.
\end{abstract}

KEYWORDS: national identity, sense of national identity, economic migrations, nurses.

„,końcem historii Francisa Fukuyamy a zderzeniem cywilizacji Samuela Huntingtona" [1] oraz dokonująca się na naszych oczach wielka dyslokacja implikują m.in. zjawisko multikulturowości, które wymusza tworzenie nowych reguł życia, społecznego porządku oraz uruchamiania mechanizmów wspierających ich rozwój. Jednym z zagadnień istotnych dla funkcjonowania współczesnego człowieka jest problematyka poczucia 
tożsamości narodowej. Pogłębiający się proces integracji europejskiej to nie tylko zmiany w sferze politycznej czy ekonomicznej, ale przede wszystkim przeobrażenia kulturowo-społeczne. W refleksji nad nową jakością otoczenia kulturowo-społecznego kluczową rolę odgrywa m.in. postępujący na naszych oczach proces migracji zarobkowej, który implikowany jest wieloma czynnikami rozwojowymi, m.in. zjawiskiem globalizacji. Społeczeństwu europejskiemu, które jest podmiotem owych zmian, towarzyszy potrzeba ponownego zdefiniowania tożsamości narodowej, a w szczególności tożsamości europejskiej. Analizowana problematyka dotyka różnych grup społeczno-zawodowych, w tym i środowiska pielęgniarskiego.

\section{Cel}

Celem niniejszej publikacji jest próba zdefiniowania tożsamości narodowej oraz poczucia tożsamości narodowej pielęgniarek w perspektywie teoretycznej. Autorzy dokonają oceny wybranych elementów, wokół których ogniskują się analizowane terminy. Inspiracją podjętej analizy jest chęć określenia ww. pojęć w kontekście zmieniającej się rzeczywistości społeczno-kulturowej oraz migracji zarobkowych, które dotykają coraz większych grup społeczno-zawodowych, w tym i środowiska pielęgniarek i położnych, a które to dyslokacje, szczególnie długoterminowe, nie pozostają bez wpływu na pojmowanie tożsamości narodowej.

\section{Materiał i metody}

Dane dotyczące omawianej tematyki uzyskano poprzez analizę źródeł literatury, zasobów internetowych.

\section{Migracje zarobkowe - analiza zjawiska}

Opis przeprowadzonego badania autorzy rozpoczną od scharakteryzowania zjawiska migracji oraz przedstawienia pojęć z nim związanych. Z analizy literaturowej wynika, że migracje, w szczególności zagraniczne, nabrały współcześnie specyficznego znaczenia, jakiego nie miały nigdy wcześniej. Jak przekonują niektórzy socjologowie, wiek XXI będzie ,,wiekiem migracji”. W dobie globalnej cywilizacji zjawisko migracji w najbliższym okresie będzie się stopniowo nasilało, „,...) będzie liczniejsze niż kiedykolwiek przedtem i powoli będzie obejmowało cały świat". W opinii tych autorów migranci będą należeć do różnych grup społecznych i etnicznych, przez co utrudniony będzie proces badawczy tego zjawiska odnoszący się do określenia konkretnych fal migracji [2]. Jak przekonują Kaczmarczyk i Okólski: „Wędrówka międzynarodowa jest zjawiskiem należącym do sfery otwartej, dostępnej dla każdego bez mała mieszkańca globu. Utraciła dawniejszy »walor« nadzwyczajności lub wyjątkowości” [3].
Dokonująca się transformacja w różnych obszarach ludzkiej egzystencji oddziałuje także na nasze potrzeby, oczekiwania, motywacje, ambicje i aspiracje. Zgodnie z teorią Germaniego projekt życia w społeczeństwie transgranicznym daje możliwość realizowania sfery aksjologicznej, w tym pozwala na zdobycie nowych kompetencji i umiejętności, stabilizacji materialnej czy też poprawy ogólnych warunków życia.

Taki stan rzeczy nie pozostaje bez wpływu na poczucie tożsamości narodowej, którą należałoby zdefiniowiniować na nowo. Powyższą tezę potwierdza Dyczewski, konstatując, że współczesnemu społeczeństwu, które jest podmiotem zmian w sferze politycznej, ekonomicznej czy kulturowo-społecznej, towarzyszy potrzeba ponownego zdefiniowania tożsamości narodowej. Zjawiska zachodzące w Europie i w świecie pobudzają więc do pełniejszego uświadomienia sobie wartości kulturowych poszczególnych państw europejskich oraz wskazują na potrzebę poszukiwania i wdrażania mechanizmów wspomagających ich rozwój w nowych warunkach u progu wielokulturowości [4].

W obliczu wędrówki ludów, które m.in. ,... z powodu konfliktów zbrojnych, niepewnych warunków ekonomicznych, walk politycznych, etnicznych i społecznych oraz kataklizmów (...) osiągnęły dziś niesłychane rozmiary i stały się masowymi ruchami, obejmującymi ogromną liczbę osób" [5], aktualne stają się pytania: kim jesteśmy my jako naród, z czym się identyfikujemy, jakie są elementy składające się na tożsamość narodową a jakie na tożsamość europejską? Czy zmierzch państwa narodowego oznacza zmierzch tożsamości narodowych oraz jak obok tożsamości narodowych kształtuje się tożsamość europejską? [6]

Dekonstrukcja granic czasu i przestrzeni zmusza niejednokrotnie jednostkę do zmiany tożsamości. Tworzenie tożsamości to często tworzenie na nowo aksjologicznych ram i hierarchii działań priorytetowych oraz drugoplanowych. Poczucie tożsamości to, obok nakreślonej hierarchii działań, wybór i realizowanie takiego zestawu aksjonormatywnego, który nada sens naszemu życiu. Poszukiwanie, identyfikacja, internalizacja oraz implementacja określonych wartości to tworzenie koncepcji własnego życia, wchodzenie w nowe role społeczno-kulturowe, co stopniowo prowadzi do reorientacji stylu życia, a w konsekwencji - do zmiany tożsamości.

Tożsamościowe następstwa migracji to zmieniające się sposoby samoidentyfikacji siebie i identyfikowania innych. Problem ten jest ważny i trudny poznawczo ze względu na trzy odmienne porządki społeczno-kulturowe, jakimi są:

- $\quad$ świat grupy pochodzenia,

- $\quad$ rzeczywistość grupy przyjmującej, 
- przestrzeń społeczno-kulturowa wytwarzana przez samych migrantów.

Często ta ostatnia przyjmuje charakter transnarodowej przestrzeni społecznej [7], ustrukturalizowanej w trakcie wędrówki przez migrantów [8], posiadającej niepowtarzalne cechy kulturowe odnoszące się do różnych porządków aksjologicznych [9].

W transnacjonalizacji (odterytorialnieniu), które implikuje zjawisko migracji współczesnych rynków pracy, a co za tym idzie - rozwój karier zawodowych w tej przestrzeni, swojej szansy na poprawę warunków socjalnych upatrują różne grupy zawodowe. Jedną z nich są pracownicy służba zdrowia, a w szczególności pielęgniarki i położne.

Z literatury przedmiotu wynika, że migracje Polaków wpisują się w ogólnoświatowy trend omawianego zjawiska, gdyż jak wynika z danych GUS, w końcu 2014 r. poza granicami Polski przebywało czasowo około 2320 tys. mieszkańców naszego kraju, tj. o 124 tys. (5,6\%) więcej niż w 2013 r. [10]. Z kolei z raportu Work Service pt. Migracje zarobkowe Polaków wynika, że poza granicami Polski przebywało czasowo około $3 \mathrm{mln}$ Polaków, co stanowiłoby nowy niechlubny rekord. Natomiast z raportu Naczelnej Rady Pielęgniarek i Położnych Zabezpieczenie społeczeństwa polskiego w świadczenia pielęgniarek i położnych wynika, że po wejściu Polski do UE wydano prawie 17,5 tys. potrzebnych do podjęcia pracy za granicą zaświadczeń o uznaniu kwalifikacji zawodowych pielęgniarek i położnych [11]. Postawić można teze, że dyslokacje tej grupy zawodowej są swego rodzaju kontestacją i manifestacją wobec ,epidemii niskich płac”, a nie buntem przeciw wykluczeniu społecznemu czy kulturalnemu.

W tym miejscu warto zauważyć, że podjęcie decyzji o emigracji, w tym i zarobkowej, wymaga w większości przypadków silnej motywacji, aby przezwyciężyć m.in. psychiczne opory związane z zerwaniem więzów rodzinnych i towarzyskich, opuszczeniem domu rodzinnego, swojej „prywatnej ojczyzny”, czy obawy przed nieznanym. Motywacja ta stanowi wypadkową pragnienia wyjazdu oraz chęci pozostania. Jest tym samym skomplikowanym jednostkowym wyborem. Według specjalistów podjęcie obecnie decyzji o wyjeździe z Polski, a także przekonanie o zasadności powrotu z emigracji wiązać należy z indywidualną oceną stanu gospodarki, a także perspektyw rozwoju własnego kraju oraz jakości życia. Na tworzenie takiego obrazu wpływają nie tylko subiektywne odczucia dotyczące warunków pracy, sytuacji dochodowej, standardu życia czy pozycji społecznej. Równie ważne są kwestie odnoszące się do możliwości rozwoju własnej drogi zawodowej. Powzięcie ostatecznego postanowienia o wyjeździe warunkuje zasada maksymalizacji użyteczności. Oczekiwane ko- rzyści z podjęcia decyzji o migracji znacznie przewyższają ewentualne straty i koszty z nią związane [12].

Drugim istotnym pojęciem, którym autorzy będą posługiwać się w niniejszym artykule, jest termin „tożsamość". Dlatego też uzasadnionym jest jego teoretyczne przedstawienie.

Termin „tożsamość”, jak konstatują Błaszczyk i Pluta, „nie jest pojęciem »samowystarczalnym«, zawsze należy dookreślić jego kontekst” [13]. Pojęcie tożsamości łączy w sobie aspekty zarówno subiektywne, jak i obiektywne. Myślenie o tożsamości kieruje uwagę na racje istnienia podmiotu/przedmiotu, na jego trwałość, odrębność, istotę, „oś konstrukcyjną". Rozmyślamy nad tym, co dla podmiotu/przedmiotu rudymentarne, neotyczne, konkretne, co go odróżnia i wyodrębnia z otoczenia. Często pojęcie tożsamości jest dookreślane przymiotnikiem. Prowadzone są rozważania na temat tożsamości narodowej, kulturowej, społecznej, indywidualnej; tożsamości przedmiotów, zjawisk, instytucji. Bazą kreowania tożsamości jest związek jednostki ze społecznością, kultur poprzez doświadczanie siebie. Jesteśmy świadkami procesów i zjawisk związanych z globalizacją i regionalizacją. Zachodzą one na płaszczyźnie społecznej, kulturowej, politycznej, gospodarczej. Ich dynamika i charakter funkcjonowania oddziałują na kondycję psychiczną człowieka, jego sferę aksjonormatywną oraz na poziom orientacji we współczesnym świecie [14]. We współczesnym ,,świecie bez granic" tożsamość nie jest dana człowiekowi raz na zawsze, lecz stanowi przedmiot ciągłej mobilności i nieustannych wyborów. Nie unikniemy zagrożeń tożsamości. Zawsze możliwe będzie pojawienie się takich faktów i informacji, które uderzą w conditio humana. Skutkiem tego może być chęć przeniesienia się do innej (lepszej) społeczności kulturowej. Tak dyslokacja, szczególnie na stałe, skutkuje często trwałą zmianą własnej tożsamości społecznej.

W dobie społeczeństwa ponowoczesnego zainteresowanie tożsamością jednostki stanowi przedmiot ciągłych analiz interdyscyplinarnych. Wiele współczesnych teorii odnoszących się do tożsamości, a tym bardziej - do kształtowania się poczucia tożsamości w cyklu życia człowieka, wywodzi się z koncepcji Erika Eriksona (1968), który po raz pierwszy użył sformułowania „tożsamość ego" (ego identity). Przedstawiciele nauk społecznych podejmujący tę problematykę uważają, że tożsamość, a w szczególności poczucie własnej tożsamości, konstytuuje się m.in. poprzez proces społeczny, jakim jest socjalizacja, dlatego też problematyka ta jest jedną z ważnych kwestii podejmowanych w badaniach oraz studiach socjologicznych.

Kierunek refleksji naukowej nazwano mianem socjologicznej teorii tożsamości jednostki. Prekursorami 
idei świadomego siebie jako podmiotu społecznego byli m.in. James, Baidwin, Cooley, Mead. Poglądy ich poddane zostały dość głębokim modyfikacjom przez następne pokolenia socjologów. Ważnym wydarzeniem w historii tego kierunku refleksji była koncepcja tożsamości jednostki zaproponowana przez Eriksona. Odtąd obszar socjologicznej teorii tożsamości jednostki w coraz większym stopniu zaczął tracić autonomię na rzecz wspomnianych analiz interdyscyplinarnych jednoczących wysiłki psychologów, pedagogów, antropologów kultury. Swoistością współczesnych socjologicznych zainteresowań problematyką tożsamości jednostki jest, jak się wydaje, koncentracja na sposobach wytwarzania tożsamości jednostki w przebiegach interakcyjnych face to face, z zaniechaniem poszukiwań w sferze trwalszych, kulturowo zdeterminowanych sposobów postrzegania siebie [15].

Jak zauważa Bokszański, wzrost zainteresowań interdyscyplinarnych powyższą problematyką wynika m.in. ze złożoności struktury społecznej, skomplikowanych wzorców wielości pełnionych przez jednostkę ról społecznych, zjawisk alienacji społecznej, ucieczki od rzeczywistości, buntu czy kontestacji rzeczywistości. Taki stan rzeczy doprowadził do sytuacji, w której jednostka będąca aktorem społecznym, umiejscowiona na poziomie usytuowanych przebiegów interakcyjnych, staje się wyraźnie świadoma siebie i zainteresowana tym, kim jest w całym obserwowanym przez nią uniwersum [15]. Ponadto czołowi współcześni myśliciele zajmujący się rozważaniami nad tożsamością (Bauman, 1993; Foucault, 1993; Talyor, 1996; Giddens, 2002; Bokszański, 2007) konstatują, że tożsamość nie jest już dzisiaj społecznie nadawana i przypisywana, lecz należy ją traktować jako zjawisko proceduralne, dynamiczne, o zmiennym charakterze. Współczesna tożsamość jest intencjonalnie i indywidualnie kreowana na podstawie indywidualnie motywowanych wyborów.

Socjologiczne pojęcie tożsamości ma bardzo wiele znaczeń i jak wskazuje analiza literaturowa, można to pojęcie rozpatrywać w różnych perspektywach teoretycznych. Tak więc socjologiczne pojęcie tożsamości odnosi się m.in. do tego, jak ludzie rozumieją sami siebie i co ma dla nich znaczenie. Nauka ta wskazuje na dwa typy tożsamości: tożsamość społeczną i tożsamość jednostkową (lub tożsamość osobistą). Istnieje między nimi różnica analityczna, ale w praktyce są one ze sobą ściśle związane [2].

Tożsamość społeczna zasadza się na potrzebach przynależności i podobieństwa do innych i związana jest z akceptacją tego, co upodabnia ludzi do siebie. Tożsamość społeczna wg Tajfela i Turnera rozumiana jest jako część koncepcji siebie jednostki, wynika z jej przynależności do określonej grupy społecznej, skła- dają się na nią trzy elementy: dostępność poznawcza przynależności (centralność), wartości i emocje wzbudzane poprzez fakt przynależności do danej grupy (afekt wewnątrzgrupowy) oraz poczucie więzi wspólnotowej z członkami danej grupy (więzi wewnątrzgrupowe) [16].

Częścią tożsamości społecznej jest tzw. tożsamość narodowa. ,,...Jest ona rozumiana jako poczucie odrębności wobec innych narodów, kształtowane między innymi przez takie czynniki, jak język, terytorium, historia narodu, świadomość pochodzenia, świadomość narodowa, kultura (jest efektem kulturalizacji, czyli wprowadzania i wchodzenia w uniwersum kultury symbolicznej)" [17]. Z kolei tożsamość osobistą rozpatrywać należy jako zjawisko per excellence immanentne, rozwój tego typu tożsamości przypisuje się strukturze i organizacji sądów osobistych. ,.(...) prawdopodobnie w pełni ukształtowaną tożsamość mają jedynie ludzie, których samowiedza tworzy strukturę hierarchiczną. Szczególnie ważne jest to, aby hierarchicznie uporządkowane były sądy dystynktywne oraz stabilne sądy centralne. Struktura taka jest najbardziej spójna i najlepiej zintegrowana. Pozwala ona spojrzeć na własną osobę jako na pewną całość. Inaczej jest z ludźmi, których samowiedza tworzy strukturę wiązkową. Ponieważ relacje między wiązkami są niejasne, nieokreślone lub w ogóle nie występują, człowiek nie może ukształtować dojrzałego przekonania o własnej tożsamości” [18]. Ponadto tożsamość osobista zakotwiczona jest w potrzebie unikalności i bazuje na dążeniu jednostki do określenia swojej niepowtarzalności w stosunku do innych ludzi i wysokim wartościowaniu samego siebie. Za podstawowe dla tożsamości Boski uznaje dwa atrybuty: kryterialny i korelatywny. Tożsamość kryterialna związana jest z wrodzonymi właściwościami organizmu człowieka oraz uwarunkowaniami wynikającymi z przynależności do danej kultury. Atrybutem kryterialnym tożsamości osobistej są więc:

- Świadomość własnej fizyczności (twarzy, postaci, głosu),

- $\quad$ pamięć autobiograficzna odnosząca się do dat ważnych w życiu człowieka, osiągnięć i porażek związanych z jego działalnością.

Atrybutem kryterialnym tożsamości społecznej są symbole kulturowe, do których należą:

- $\quad$ zakres wiedzy i znajomość otaczającego świata,

- znaczenia osobiste przypisywane do fragmentów rzeczywistości i systemu wartości obowiązującego w kulturze,

- symbole przynależności do grupy społecznej, pozwalające na samoidentyfikację.

Atrybuty korelatywne są to nabyte właściwości osobowościowe, indywidualne cechy osobowości zgodne z typologią tych cech, obowiązującą w społeczeństwie 
i kulturze. Do atrybutów korelatywnych tożsamości osobistej Boski zalicza:

- $\quad$ cechy przymiotnikowe używane na określenie osobowości (np. poważny, uczciwy itp.),

- podstawowe wymiary osobowości, takie jak: ekstrawersja, lęk, inteligencja.

Za podstawowe atrybuty tożsamości społecznej Boski uważa wartości kulturowe, przekazywane w procesie socjalizacji i podlegające internalizacji, oraz zbieżność obrazu samego siebie z prototypami istniejącymi w społeczeństwie [19].

W obszarze zainteresowań psychologii problematykę tożsamości odnajdujemy w nowej orientacji fenomenologiczno-egzystencjalnej, która powstała jako kompilacja dwóch nurtów. Pierwszy nawiązuje do Heideggera i jego egzystencjalnej koncepcji człowieka istniejącego w świecie, drugi odnosi się do fenomenologii Hussera. Takie podejście do tożsamości uwzględnia trzy wymiary ludzkiego istnienia: ,ja - świat natury”, ,,ja - świat relacji międzyludzkich” oraz ,ja - świat własnych właściwości fizycznych, charakterologicznych”, „świat ustosunkowań do samego siebie". Frank zwraca szczególną uwagę na napięcie w doświadczeniu relacji ,,ja - świat". Odkrywanie świata obiektywnych wartości jest jednocześnie odkryciem więzi z ponadindywidualną całością, ujrzeniem nowego, pełniejszego wymiaru ludzkiego istnienia, doświadczeniem bycia częścią większej całości. Ukierunkowanie na wartości (szczególnie na tzw. wartości ostateczne) pozwala jednostce przekraczać aktualny stan i odkryć nowy sens relacji „ja - świat”. Odkrycie świata obiektywnych wartości jest także, zdaniem Franka, odnalezieniem i poznaniem samego siebie [20].

W tym miejscu należy nadmienić, że w perspektywie psychologicznej tożsamość człowieka rozpatrywana jest w dwóch aspektach: subiektywnym i obiektywnym. Aspekt subiektywny to przeżywanie przez samąjednostkę swej stałości, to percepcja własnej postaci, każdej części ciała, psychiki. Powstaje ona w biegu życia, w tysiącach różnych zdarzeń i interakcji, wykonywanych zadaniach, realizowanych planach [21]. Tożsamość w ujęciu obiektywnym to przede wszystkim bycie tym samym w ocenach postrzegających nas ludzi (twoje ruchy, twój chód, gesty, uśmiech, twój styl), to sposób postrzegania jednostki przez innych, społeczna ocena psychologicznego aspektu tożsamości - ,kim ona jest?”.

$\mathrm{Na}$ koniec rozważmy pojęcie tożsamości w ujęciu pedagogicznym. Zdaniem Nikitorowicza jest ona wynikiem kontaktu jednostki z innymi grupami, sposobem określania samego siebie przez przynależność do różnego typu grup społecznych. Tożsamość jednych grup może być oparta na religii, wspólnocie dziejów, na wierze w wywodzenie się od tych samych przodków, innych - na posługiwaniu się tym samym językiem czy mieszkaniu na określonym terytorium, wspólnocie obyczajów i zwyczajów. Tożsamość można określić jako spotkanie teraźniejszości z przeszłością i antycypowaną przyszłością. Wyrasta ona ze świadomego orientowania się ludzi na wartości grupy, które decydują o swoistości i odrębności, wyrażając się w emocjonalnym stosunku do wartości. Stąd mała ojczyzna, prywatna ojczyzna, tutejszość, swojska obyczajowość, zakorzenienie. Tożsamość grupowa stanowi zestaw wartości i celów strukturalizujących życie jednostki, które są nierozerwalne z ludzką egzystencją i z takimi pojęciami, jak: wolność i wybór, odpowiedzialność i zobowiązanie przed sobą i grupą. Człowiek bez zobowiązań nie posiada odpowiedzialności i tym samym jest pozbawiony wolności, stąd osobista tożsamość jest zawsze społeczną tożsamością [22].

Ważnym zagadnieniem odnoszącym się do niniejszego artykułu jest także rozróżnienie pojęcia tożsamości od poczucia tożsamości, czyli subiektywnego postrzegania siebie, które - jak stwierdza Maclntyre „,...jest jednym z produktów społecznej konstrukcji podejmowanej przez aktorów społecznych, wytworzonym w interakcjach, gdzie ludzie zdają sobie sprawę ze swoich działań przez sytuowanie ich we własnej opowieści" [23]. Rozróżnienie tych pojęć jest wynikiem oddzielenia perspektywy zewnętrznej od podmiotowej. Pojęcie tożsamości bywa wiązane z treściami zewnętrznej, tworzonej i przekazywanej jej przez otoczenie w procesach socjalizacji, definicji jednostki. Mechanizmy kształtowania się tak rozumianej tożsamości nie zawsze jednak prowadzą do internalizacji owych treści. Jednostka może nie tylko przekształcić, lecz także odrzucić oferowaną jej tożsamość, stwarzając alternatywny zespół wyobrażeń dotyczących własnej osoby. Przykładem tego zjawiska są np. problemy tożsamości interseksualistów, osób dokonujących konwersji religijnej czy zmieniających przynależność państwową. Problemy te dowodzą, że tożsamość przypisywana nie musi pokrywać się z tożsamością przez jednostkę przyjętą lub doświadczaną. Tak rozumiana tożsamość własna (poczucie tożsamości) manifestuje się w dwóch wymiarach. Jednym z nich jest aspekt unikalności i odróżniania się od innych ludzi, drugim - aspekt wspólnoty i podobieństwa. Poczucie odrębności jest uwarunkowane świadomością względnie stałych cech indywidualnych wyróżniających podmiot spośród wielu jemu podobnych. Poczucie wspólnoty buduje świadomość cech podzielanych z innymi ludźmi. Dwoistość składowych tożsamości własnej daje przy tym bodziec do wyodrębnienia subsystemów tożsamości osobistej i tożsamości społecznej [24].

\section{Podsumowanie}

Przedstawiona w tej pracy analiza porusza zagadnienie aksjologicznych korelatów tożsamości narodowej 
oraz poczucia tożsamości narodowej. Dokonujące się na naszych oczach zmiany niemal w każdym wymiarze ludzkiego życia, w szczególności narastające zjawisko transgraniczności i towarzysząca jej transkulturowość, które są wynikiem m.in. globalizacji, spowodowały, że współczesny świat społeczny powoli staje się światem jednego narodu. Jak pokazuje analiza literaturowa, w tych zmianach przedstawiciele różnych grup zawodowych, w tym i pracownicy służby zdrowia, dostrzegają dla siebie szansę na lepsze zarobki czy też poprawę warunków pracy. W związku z powyższym istnieje potrzeba modyfikacji lub ponownego definiowania wielu pojęć, w tym tożsamości narodowej, europejskiej czy też poczucia tożsamości narodowej, jak również odsłaniania nowych, pełniejszych aspektów zjawiska tożsamości, tym bardziej że sytuuje się ono w sferze zjawisk cechujących się znaczną dynamicznością i dlatego wymaga podejmowania systematycznych, interdyscyplinarnych analiz oraz badań o charakterze eksploracyjno-diagnostycznych.

\section{Piśmiennictwo}

1. Szopski M. Dylematy wielokulturowości w metropoliach Europy. Warszawa: Szkoła Wyższa Psychologii Społecznej; 1998. 48.

2. Giddens A. Socjologia. Warszawa: PWN; 2006. 52, 282.

3. Kaczmarczyk P, Okólski M. Migracje specjalistów wysokiej klasy w kontekście członkostwa Polski w Unii Europejskiej. Warszawa: Wyd. Urząd Komitetu Integracji Europejskiej, Departament Analiz i Strategii; 2005. 7.

4. Dyczewski L. Naród podmiotem kultury. W: Dyczewski L (red.). Tożsamość polska i otwartość na inne społeczeństwa. Lublin: Wyd. KUL; 1996. 7.

5. Jan Paweł II. Posynodalna adhortacja apostolska. Rozdz. VII. 2003; $\mathrm{nr} 72$.

6. Nikitorowicz J. Tożsamość w edukacyjnym procesie wielokulturowym. W: Urlińska M (red.). Edukacja a tożsamość etniczna. Materiały z konferencji naukowej w Rabce. Toruń 1995. 117.

7. Faist T. The Volume and Dynamics of International Migration and Transnational Social Space. Oxford: Oxford University Press; 2002. 7.

8. Morawska E. Disciplinary agendas and analytic strategies of research on immigration and transnationalism. Int Migr Rev. 2003; 3(27): 611-640.

9. Niedźwiedzki D. Migracje i tożsamość. Od teorii do analizy przypadku. Kraków: Wyd. NOMOS; 2010. 10.

10. GUS. Informacja o rozmiarach i kierunkach czasowej emigracji z Polski w latach 2004-2014.

11. (Dostępne w Internecie:) http://stat.gov.pl/obszary-tematyczne/ludnosc/migracje-zagraniczne-ludnosci/informacja-o-rozmiarach-i-kierunkach-emigracji-z-polski-w-latach20042015,2,9.html (data dostępu: 12.07.2016).

12. W Polsce zabraknie pielęgniarek, http://www.pulshr.pl/rynek-zdrowia/w-polsce-zabraknie-pielegniarek,27215.htm (data dostępu: 12.07.2016).
13. Bera R. Aksjologiczny sens pracy a poczucie jakości życia młodych emigrantów polskich. Lublin: Wyd. UMCS; 2008. 103.

14. Błaszczyk M, Pluta J. Tożsamość układu lokalnego a problem reintegracji. W: Szlachcicowa I (red.). Religia - przekonania - tożsamość: szkice socjologiczne. Acta Universitatis Wratislaviensis. Socjologia. 1998; 26: 116.

15. Chałas K. Globalizacja wyzwaniem do kreowania tożsamości w procesie edukacji. W: Kojsa W (red.). Edukacyjne konteksty procesów globalizacji. Cieszyn: Uniwersytet Śląski. Filia w Cieszynie; 2001. 83-84.

16. Bokszański Z. Tożsamość, biografia i system działania - perspektywa Floriana Znanieckiego. W: Machaj I (red.). Małe struktury społeczne. Lublin: Wyd. UMCS; 2004. 121-123.

17. Cameron JE, Lalonde RN. Social identification and genderrelated ideology in women and men. Brit $\mathrm{J}$ Soc Psychol. 2001; 40: 59-77.

18. Przybysz PJ. Stereotyp a tożsamość narodowa. Kilka uwag na marginesie książki H. Sienkiewicza „Ogniem i mieczem”. W: Szwed R (red.). Dylematy tożsamości zbiorowych. Przyczynek do rozważań nad tożsamością ukraińską, polską i europejską. Lublin: Wyd. KUL; 2007. 79-98.

19. Kozielecki J. Psychologiczna teoria samowiedzy. Warszawa: PWN; 1986. 331-332.

20. Mielicka H. Proces rozwoju tożsamości. W: Mielicka $H$ (oprac.). Socjologia wychowania. Wybór tekstów. Kielce: Wyd. Stachurski; 2000. 28-29.

21. Kociuba J. Tożsamość aktora. Lublin: Wyd. UMCS; 1996. 35-36.

22. Rybczyńska DA, Olszak-Krzyżanowska B. Aksjologia pracy socjalnej - wybrane zagadnienia. Warszawa: Wyd. Scholar; 1995. 11.

23. Nikitorowicz J. Tożsamość - istota, geneza, wymiary. W: Pilch T (red.). Encyklopedia pedagogiczna XXI wieku. Warszawa: Wyd. Żak; 2007. 757.

24. Kostera M. Współczesne koncepcje zarządzania. Warszawa: Wyd. Nauk. Wydziału Zarządzania Uniwersytetu Warszawskiego; 2008. 87.

25. Błeszyńska KM. Tożsamość - orientacje teoretyczno-metodologiczne. W: Pilch T (red.). Encyklopedia pedagogiczna XXI wieku. Warszawa: Wyd. Żak; 2007. 769-770.

Artykuł przyjęty do redakcji: 20.07.2016

Artykuł przyjęty do publikacji: 05.09.2016

Źródło finansowania: Praca nie jest finansowana z żadnego źródła. Konflikt interesów: Autorzy deklarują brak konfliktu interesów.

Adres do korespondencji:

Renata Rasińska

ul. Mariana Smoluchowskiego 11

60-179 Poznań

tel.: 618612254

e-mail: rasinska@ump.edu.pl

Zakład Organizacji i Zarządzania w Opiece Zdrowotnej

Uniwersytet Medyczny im. Karola Marcinkowskiego w Poznaniu 